\title{
HUBUNGAN KEMAMPUAN KOMUNIKASI MATEMATIS DAN RESILIENSI MATEMATIS SISWA SEKOLAH MENENGAH ATAS
}

\author{
${ }^{1 *}$ Vika Rosa, ${ }^{2}$ Halini, ${ }^{3}$ Hamdani \\ ${ }^{1,2,3}$ Program Studi Pendidikan Matematika FKIP Universitas Tanjungpura Pontianak \\ Email: vikarosa1998@gmail.com
}

\begin{abstract}
This research aimed to describe mathematical communication skills, mathematical resilience, and the relationship between mathematical communication skills and mathematical resilience. This research used a quantitative approach with a correlation research design. The population in this study were students of grade XI SMA Negeri 2 Teluk Keramat and the sample was students of grade XI MIPA 2.The results showed that the mathematical communication skills students tend to have is the ability to express mathematical concepts by stating daily events in language or mathematical symbols (mathematical expression ability) which were able to be achieved by the students as much as $62 \%$. Whereas for mathematical resilience that students tend to have is to have curiosity, reflect, research, and make use of various sources in mathematics learning, which contributed $38.7 \%$ and were able to be achieved by 16 students (76\%). Furthermore, based on the results of the Pearson Product Moment correlation test, a significance value of 0.021 and a correlation value of 0.500 was obtained. So it can be concluded that there is a significant relationship between mathematical communication skills, mathematical resilience, and the strength of the correlation between the two variables is classified as moderate.
\end{abstract}

Keywords: Correlation, Mathematical Communication Skills, Mathematical Resilience

\section{Pendahuluan}

National Council of Teaching Matemathics (NCTM) (2000, h.77) menyatakan bahwa proses matematika standar di sekolah meliputi pemecahan masalah, komunikasi, penalaran dan pembuktian, koneksi dan presentasi merupakan kemampuan yang harus dimiliki siswa. Sejalan dengan itu, dalam Permendikbud Nomor 59 Tahun 2014 tentang Kurikulum 2013 Sekolah Menengah Atas/Madrasah Aliyah dikemukakan bahwa pembelajaran matematika Sekolah Menengah Atas (SMA) memiliki tujuan di antaranya yaitu siswa dapat menggunakan kalimat lengkap, tabel, simbol, diagram, atau media lain untuk mengkomunikasikan ide, alasan dan menyusun bukti matematis untuk memperjelas situasi atau masalah.. Ini menyiratkan bahwa pendidikan matematika sekolah bertujuan antara lain supaya siswa memiliki kemampuan komunikasi yang baik, khususnya dalam menyelesaikan masalah matematika. Pentingnya kemampuan komunikasi dalam menunjang proses belajar siswa adalah apabila memiliki kemampuan komunikasi yang baik siswa mampu menyampaikan pemahamannya terhadap konsep dengan cara mengekpsresikan, menggambarkan, dan menjelaskan ide-ide matematika.

Namun, berdasarkan beberapa hasil penelitian dilaporkan bahwa kemampuan komunikasi matematis siswa tergolong rendah. Menurut penelitian Wulandari (2014, h.8) hanya $19 \%$ siswa yang mempunyai kemampuan komunikasi matematis yang cukup tinggi, sedangkan siswa lainnya mempunyai kemampuan komunikasi yang rendah. Rendahnya kemampuan komunikasi matematis siswa karena siswa yang belum mampu menyatakan masalah berbentuk soal cerita, gambar, dan benda nyata ke dalam model 
Vol 2 No 1 Juli 2021

Jurnal AlphaEuclidEdu

Received:11/04/2021; Resived:20/06/2021; Accepted:10/07/2021

matematika, serta belum mampu menjelaskan jawaban secara tertulis pada materi sistem persamaan linear dua variabel (SPLDV). Sedangkan penelitian lainnya, Rahmawati, Bernard, dan Akbar (2019, hh.347-348) mengungkapkan bahwa hanya dua dari empat indikator kemampuan komunikasi matematis yang mampu dicapai siswa sehingga kemampuan komunikasi matematisnya dikategorikan rendah. Rendahnya kemampuan komunikasi matematis siswa karena siswa belum mampu mengungkapkan masalah sehari-hari ke dalam bahasa matematika dan belum mampu membuat grafik materi sistem persamaan linear dua variabel (SPLDV). Hal itu juga diperkuat oleh hasil prariset peneliti kepada tiga siswa kelas XI dari beberapa SMA di Pontianak dengan memberikan soal program linear. Peneliti memilih materi program linear karena dalam penyelesaian masalah materi tersebut menuntut kemampuan komunikasi matematis siswa seperti merumuskan model matematika, membuat grafik, dan menjelaskan jawabannya dengan bahasa sendiri. Berdasarkan jawaban atas pertanyaan prariset, dapat diketahui bahwa ketiga siswa tersebut masih memiliki kesalahan dalam merumuskan model matematika, masih salah dalam membuat grafik, dan masih salah dalam menjelaskan jawabannya dengan bahasa sendiri. Ini mengindikasikan kemampuan komunikasi matematis ketiga siswa tersebut masih rendah karena belum bisa mengungkapkan masalah ke dalam model matematika, belum bisa membuat grafik, serta belum bisa menjelaskan jawaban menggunakan bahasa sendiri.

Berdasarkan hasil wawancara dengan ketiga siswa diperoleh informasi mengenai upaya mereka dalam menyelesaikan masalah. Seorang siswa berusaha menyelesaikan masalah sekuat tenaga dengan melakukan berbagai cara yang diketahuinya hingga memperoleh solusi. Sedangkan dua orang siswa lainnya menyelesaikan masalah sesuai dengan kemampuan yang dimilikinya saja. Siswa tersebut menganggap masalah tersebut sulit untuk diselesaikan sehingga ia lebih memilih untuk menjawab semampunya saja bahkan tidak mau berusaha untuk mencari cara lain untuk memperoleh solusi. Menurut hasil prariset tampak bahwa siswa memiliki sikap tidak mudah menyerah atau daya juang yang bervariasi dalam menyelesaikan masalah yang diberikan. Sikap tidak menyerah ketika menghadapi masalah meruvakan satu di antara bentuk resiliensi matematis. Johnston-Wilder dan Lee (2010b) menyatakan bahwa, "Mathematical resilience mean a positive affective stance to mathematics" (h.2), yang berarti bahwa resiliensi matematis merupakan suatu sikap afektif positif terhadap matematika. Resiliensi matematis memiliki empat faktor yaitu: (a) akan bertahan ketika menghadapi kesulitan, (b) dapat bekerja sama dengan teman sebayanya, (c) miliki keterampilan bahasa yang diperlukan untuk mengekspresikan pemahamannya, dan (d) menyadari bahwa semakin banyak mereka berusaha dalam pembelajaran matematika maka mereka berhasil (Johnston-Wilder dan Lee, 2010b, h.2).

Dalam menyelesaikan masalah siswa tidak hanya dituntut untuk memiliki sikap tidak mudah menyerah atau daya juang, tetapi siswa juga dituntut untuk mampu menyampaikan gagasan matematika baik secara lisan maupun tulisan. Siswa yang memperoleh peningkatan dalam komunikasi matematis secara verbal yang efektif juga meningkatkan pemahaman konseptual, self-efficacy, dan resiliensi matematis (Boaler, 
Vol 2 No 1 Juli 2021

Jurnal AlphaEuclidEdu

Received:11/04/2021; Resived:20/06/2021; Accepted:10/07/2021

2009; Johnston-Wilder dan Lee, 2010b). Hal ini sejalan dengan hasil penelitian Rifdah dan Priatna (2019, h.4) yaitu terdapat hubungan antara kemampuan komunikasi dan resiliensi matematis siswa. Namun, penelitian tersebut dilakukan di Sekolah Menengah Pertama (SMP) yaitu siswa-siswanya merupakan remaja awal. Menurut Gunarsa dan Gunarsa (2001) dan Mappiare (2000) (dalam Putro, 2017, h.29) masa remaja awal memiliki keadaan yang tidak stabil dan lebih emosional dibandingkan dengan remaja pertengahan dan remaja akhir. Jadi, peneliti tertarik melakukan penelitian pada remaja pertengahan yaitu siswa SMA dengan judul penelitian "Hubungan Kemampuan Komunikasi Matematis dan Resiliensi Matematis Siswa Sekolah Menengah Atas”.

\section{Metode Penelitian}

Tujuan penelitian ini yaitu mengungkap hubungan antara kemampuan komunikasi matematis dan resiliensi matematis yang dimiliki oleh siswa. Berdasarkan tujuan tersebut maka digunakan metode penelitian kuantitatif dengan jenis penelitian korelasi. Variabel penelitian ini adalah kemampuan komunikasi matematis $\left(\mathrm{X}_{1}\right)$ dan resiliensi matematis $\left(\mathrm{X}_{2}\right)$. Populasi penelitian yaitu siswa kelas XI SMA Negeri 2 Teluk Keramat tahun pelajaran 2020/2021 yang telah mempelajari materi Program Linear. Sedangkan sampel yang dipilih yaitu siswa kelas XI MIPA 2 SMA Negeri 2 Teluk Keramat tahun pelajaran 2020/2021 yang berjumlah 21 siswa. Teknik pengambilan sampel yang digunakan adalah teknik purposive sampling, yaitu pemilihan sampel berdasarkan beberapa pertimbangan, karena dalam menentukan kelas sebagai sampel penelitian didasarkan pada pertimbangan guru matematika SMA Negeri 2 Teluk Keramat.

Prosedur penelitian yang digunakan meliputi tiga tahap yaitu tahap persiapan, tahap pelaksanaan dan tahap akhir. Tahap persiapan dimulai dengan menyusun desain penelitian dan instrumen penelitian. Instrumen penelitian tersebut dilakukan uji validitas yaitu validitas isi dan validitas butir. Validitas isi untuk soal tes divalidasi oleh satu orang dosen Pendidikan Matematika FKIP Universitas Tanjungpura dan dua orang guru matematika SMA Negeri 2 Teluk Keramat, sedangkan validitas isi untuk angket resiliensi matematis divalidasi oleh satu orang dosen yang ahli pada bidang psikologi. Instrumen penelitian selanjutnya diujicobakan kepada siswa kelas XI MIPA 1 SMA Negeri 2 Teluk Keramat untuk melihat validitas butir, reliabilitas, indeks kesukaran soal, dan daya pembeda soal. Setelah instrumen penelitian direvisi sesuai dengan hasil uji coba, kemudian dilakukan tahap pelaksanaan yaitu penelitian dengan memberikan tes kemampuan komunikasi matematis siswa secara tertulis berupa soal uraian (essay) materi program linear, memberikan angket resiliensi matematis siswa berupa pernyataan yang menyediakan empat pilihan jawaban yaitu Sangat Setuju (SS), Setuju (S), Tidak Setuju (TS), Sangat Tidak Setuju (STS), dan melakukan wawancara untuk memperoleh informasi yang lebih mendalam tentang kemampuan komunikasi matematis siswa.

Hasil skor kemampuan komunikasi matematis dan skor angket resiliensi matematis dianalisis pencapaian indikatornya. Angket resiliensi matematis yang berbentuk data ordinal dikonversi ke data interval terlebih dahulu menggunakan Method of Successive Interval (MSI) dengan bantuan Microsoft Excel serta program tambahan perhitungan 
Vol 2 No 1 Juli 2021

Jurnal AlphaEuclidEdu

Received:11/04/2021; Resived:20/06/2021; Accepted:10/07/2021

MSI yaitu sta97.xla. Setelah selesai mengubah data ordinal ke data interval, selanjutnya dilakukan analisis statistik terhadap data yang diperoleh dengan bantuan program IBM SPSS Statistics 24 untuk melihat hubungan antara kemampuan komunikasi matematis dan resiliensi matematis siswa. Namun, sebelum melakukan uji korelasi data tersebut harus dilakukan uji normalitas, uji homogenitas, dan uji linearitas. Data yang telah memenuhi uji prasyarat dilakukan uji korelasi menggunakan Pearson Product Moment. Setelah menganalisis data, selanjutnya adalah melakukan penarikan kesimpulan dengan mengambil intisari dari data yang disajikan kemudian dikemukakan disertai oleh buktibukti yang valid yang diungkapkan dalam kalimat yang ringkas, jelas dan mudah dipahami.

\section{Hasil Penelitian dan Pembahasan}

\section{Hasil Penelitian}

\section{Hasil Tes Kemampuan Komunikasi Matematis Siswa}

Terdapat tiga indikator yang digunakan untuk mengukur kemampuan komunikasi matematis siswa, yaitu (a) written text ability, yaitu kemampuan memberikan jawaban dengan menggunakan bahasa sendiri, membuat model situasi atau persoalan menggunakan lisan, tulisan, konkrit, grafik dan aljabar, menjelaskan dan membuat pertanyaan tentang matematika yang telah dipelajari, mendengarkan, mendiskusikan, dan menulis tentang matematika, membuat konjektur, menyusun argumen, dan generalisasi secara tertulis, (b) drawing ability, yaitu kemampuan merefleksikan bendabenda nyata, gambar, dan diagram ke dalam ide-ide matematika secara tertulis, dan (c) mathematical expression ability, yaitu kemampuan mengekspresikan konsep matematika dengan menyatakan peristiwa sehari-hari dalam bahasa atau simbol matematika secara tertulis.

Adapun pencapaian indikator siswa pada soal tes kemampuan komunikasi matematis diketahui bahwa hanya indikator mathematical expression ability yang mampu dicapai oleh siswa melalui jawaban secara tertulis. Untuk soal nomor satu tidak ada siswa yang mampu mencapai indikator written text ability, sedangkan siswa yang mampu mencapai indikator mathematical expression ability sebanyak 5 orang (24\%). Untuk soal nomor dua siswa yang mampu mencapai indikator mathematical expression ability sebanyak 21 orang $(100 \%)$ dan tidak ada $(0 \%)$ siswa yang mampu mencapai indikator written text ability. Sedangkan soal nomor tiga tidak ada $(0 \%)$ siswa yang mampu mencapai indikator drawing ability dan indikator written text ability.

\section{Hasil Angket Resiliensi Matematis Siswa}

Terdapat enam indikator yang digunakan untuk mengukur resiliensi matematis siswa, yaitu siswa menunjukkan sikap tekun, yakin/percaya diri, bekerja keras dan tidak mudah menyerah menghadapi masalah, kegagalan, dan ketidakpastian dalam pembelajaran matematika (indikator satu), siswa menunjukkan keinginan bersosialisasi, mudah memberi bantuan, berdiskusi dengan sebayanya, dan beradaptasi dengan lingkungannya dalam pembelajaran matematika (indikator dua), siswa memunculkan ide/cara baru dan mencari solusi kreatif terhadap tantangan dalam pembelajaran 
Vol 2 No 1 Juli 2021

Jurnal AlphaEuclidEdu

Received:11/04/2021; Resived:20/06/2021; Accepted:10/07/2021

masalah matematika (indikator tiga), siswa menggunakan pengalaman kegagalan untuk membangun motivasi diri dalam pembelajaran matematika (indikator empat), siswa memiliki rasa ingin tahu, merefleksi, meneliti, dan memanfaatkan beragam sumber dalam pembelajaran matematika (indikator lima), dan siswa memiliki kemampuan mengontrol diri; sadar akan perasaannya dalam pembelajaran matematika (indikator 6). Adapun pencapaian indikator siswa pada angket resiliensi matematis diketahui bahwa siswa yang mampu mencapai indikator satu sebanyak 11 orang (52\%), siswa yang mampu mencapai indikator dua sebanyak 12 orang (57\%), siswa yang mampu mencapai indikator tiga sebanyak 12 orang (57\%), siswa yang mampu mencapai indikator empat sebanyak 15 orang (71\%), siswa yang mampu mencapai indikator lima sebanyak 16 orang (76\%), dan siswa yang mampu mencapai indikator enam sebanyak 8 orang $(38 \%)$.

\section{Hasil Wawancara}

Hasil wawancara diperoleh informasi untuk indikator written text ability ketika peneliti meminta siswa untuk menjelaskan kembali mengenai alasan dari pendapat yang mereka berikan, diketahui ketiga siswa tersebut memberikan alasan yang lebih rinci walaupun maksud dari alasan tersebut masih sama seperti jawaban dalam tes tertulis sehingga alasan yang diberikan masih kurang lengkap dan tepat. Siswa P menyampaikan bahwa terdapat tiga titik sudut yang diuji untuk memperoleh solusi, namun hanya satu titik sudut yang benar, sedangkan dua titik sudut lainnya salah. Siswa TH menyampaikan bahwa terdapat lebih dari satu titik sudut yang diuji untuk memperoleh solusi dari masalah yang diberikan misalnya titik $(0,0)$, siswa tersebut juga berpendapat bahwa akan lebih mudah menemukan titik-titik sudut yang lain apabila membuat grafik daerah penyelesaian. Sedangkan siswa NS menyampaikan bahwa hanya ada satu titik sudut yang diuji untuk memperoleh solusi dari masalah yang diberikan karena siswa tersebut langsung melakukan eliminasi dan substitusi terhadap kedua persamaan yang ia tulis. Setelah peneliti meluruskan pernyataan dari siswa NS, siswa tersebut baru menyadari bahwa ada titik-titik sudut lain yang bisa didapatkan dari fungsi kendala, satu di antaranya adalah titik $(0,0)$. Untuk indikator drawing ability, siswa NS dan TH juga menyampaikan bahwa ia kurang teliti dalam memahami masalah yang diberikan. Sedangkan siswa $\mathrm{P}$ menyampaikan bahwa ia lupa untuk mengarsir daerah penyelesaiannya. Untuk indikator mathematical expression ability, siswa $\mathrm{P}$ dapat menjelaskan alasan menggunakan tanda pertidaksamaan $\leq$ (lebih dari atau sama dengan) pada model matematika dengan benar dan menyadari bahwa terdapat kesalahan menulis tanda $=$ (sama dengan) pada model matematika karena kurang teliti. Siswa TH tidak dapat menjelaskan alasan menggunakan tanda pertidaksamaan $\leq$ (lebih dari atau sama dengan) pada model matematika yang ia tulis karena lupa, meskipun peneliti sudah mencoba memberikan bayangan mengenai jawaban siswa TH pada tes tertulis. Sedangkan siswa NS dapat menjelaskan alasan menggunakan tanda pertidaksamaan $\leq$ (lebih dari atau sama dengan) pada model matematika yang ia buat dengan benar.

Hubungan Kemampuan Komunikasi Matematis dan Resiliensi Matematis Siswa 
Vol 2 No 1 Juli 2021

Jurnal AlphaEuclidEdu

Received:11/04/2021; Resived:20/06/2021; Accepted:10/07/2021

Hubungan antara kemampuan komunikasi matematis dan resiliensi matematis siswa dianalisis untuk mengujian hipotesis penelitian. Uji korelasi yang digunakan untuk mencari hubungan kemampuan komunikasi matematis dan resiliensi matematis siswa yaitu uji statistik parametrik Pearson Product Moment dibantu program IBM SPSS Statistics 24. Namun sebelum korelasi data dianalisis, hasil penelitian harus dilakukan uji normalitas, uji homogenitas, dan uji linearitas. Uji normalitas menunjukkan bahwa nilai Asymp. Sig. (2-tailed) yaitu sebesar 0,052 untuk kemampuan komunikasi matematis dan 0,079 untuk resiliensi matematis, sehingga masing-masing data tersebut berdistribusi normal karena nilai signifikannya lebih besar dari nilai $\alpha(\alpha=0,05)$. Uji homogenitas menunjukkan nilai signifikan yang dihasilkan sebesar 0,076, jadi data tersebut diambil dari sampel yang homogen karena nilai signifikan yang dihasilkan lebih besar dari nilai $\alpha$. Uji linearitas menunjukkan nilai signifikan yang dihasilkan sebesar 0,434, sehingga kemampuan komunikasi matematis dan resiliensi matematis memiliki hubungan yang linear karena nilai signifikan Deviation from Linearity yang dihasilkan lebih besar dari nilai $\alpha$.

Menurut hasil uji korelasi Pearson Product Moment nilai signifikan yang diperoleh antara kedua variabel yaitu sebesar $0,021<0,05$, jadi $\mathrm{H}_{0}$ ditolak dan berakibat diterimanya $\mathrm{H}_{\mathrm{a}}$. Oleh sebab itu, dapat dikatakan bahwa ada hubungan yang signifikan antara kemampuan komunikasi matematis dan resiliensi matematis siswa. Nilai koefisien korelasi sebesar 0,500 menunjukkan korelasi antara dua variabel adalah korelasi positif artinya jika siswa memiliki kemampuan komunikasi matematis yang tinggi maka resiliensi matematisnya juga tinggi, begitu pula sebaliknya.

\section{Pembahasan}

\section{Kemampuan Komunikasi Matematis Siswa}

Kemampuan komunikasi matematis siswa dilihat berdasarkan hasil jawaban siswa dalam menyelesaikan soal tes materi program linear yang memuat indikator-indikator kemampuan komunikasi matematis. Berdasarkan hasil penelitian, secara rata-rata sebanyak $62 \%$ siswa mampu mencapai indikator mathematical expression ability. Sedangkan indikator written text ability dan drawing ability tidak ada satupun (0\%) siswa yang mampu mencapai indikator tersebut. Berdasarkan ketercapaian masingmasing indikator tempak bahwa siswa rendah pada written text ability dan drawing ability, sedangkan mathematical expression ability beberapa siswa sudah cukup baik. Hal tersebut disebabkan oleh tiga faktor yang disimpulkan berdasarkan hasil jawaban dan wawancara yang dilakukan, yaitu: (a) rata-rata siswa belum mampu mencapai indikator written text ability karena siswa belum mampu mengkomunikasikan alasan dengan lengkap dan tepat dalam menyelesaikan masalah yang diberikan dan tidak memberikan argumen dari solusi yang diperoleh, (b) rata-rata siswa belum mampu mencapai indikator drawing ability karena siswa belum mampu menentukan titik-titik potong dan daerah penyelesaian pada grafik dengan tepat, dan (c) beberapa siswa yang belum mampu mencapai indikator mathematical expression ability karena kurangnya pemahaman yang menyeluruh tentang masalah yang diberikan, jadi siswa belum mampu menggunakan tanda pertidaksamaan pada fungsi kendala dengan benar. 
Vol 2 No 1 Juli 2021

Jurnal AlphaEuclidEdu

Received:11/04/2021; Resived:20/06/2021; Accepted:10/07/2021

Menurut hasil penelitian Wulandari (2018, h.8) tentang Kemampuan Komunikasi Matematis Siswa Ditinjau dari Gaya Belajar pada SMA Negeri 10 Pontianak menunjukkan kemampuan komunikasi matematis siswa rendah pada kemampuan mengungkapkan masalah berbentuk soal cerita, gambar, dan benda nyata ke dalam model matematika dan kemampuan menjelaskan jawaban secara tertulis. Sedangkan penelitian lainnya, Rahmawati, Bernard, dan Akbar (2019, hh.347-348) tentang Analisis Kemampuan Komunikasi Matematik Siswa SMK pada Materi Sistem Persamaan Linear Dua Variabel (SPLDV) menunjukkan kemampuan komunikasi matematis siswa rendah pada kemampuan mengungkapkan masalah sehari-hari dalam bahasa matematika dan kemampuan membuat grafik. Apabila kedua hasil penelitian di atas dibandingkan dengan hasil tes kemampuan komunikasi matematis siswa dalam penelitian ini maka hasil penelitian tersebut menjadi relevan. Hasil penelitian ini menunjukkan kemampuan komunikasi matematika siswa rendah pada written text ability dan drawing ability. Hasil yang tidak jauh berbeda dari kedua penelitian terdahulu tersebut. Jadi, diperlukan upaya guru maupun siswa untuk meningkatkan kemampuan komunikasi matematis siswa mengingat kemampuan komunikasi matematis berperan penting dalam pembelajaran matematika.

\section{Resiliensi Matematis Siswa}

Resiliensi matematis siswa dilihat dari hasil angket yang memuat indikatorindikator resiliensi matematis. Indikator siswa menunjukkan sikap tekun, yakin/percaya diri, bekerja keras dan tidak mudah menyerah menghadapi masalah, kegagalan, ketidakpastian dalam menyelesaikan masalah program linear memberikan sumbangan sebesar $27,8 \%$ terhadap resiliensi matematis siswa dan mampu dicapai oleh 11 orang siswa (52\%). Indikator siswa menunjukkan keinginan bersosialisasi, mudah memberi bantuan, berdiskusi dengan sebayanya, dan beradaptasi dengan lingkungannya dalam pembelajaran matematika memberikan sumbangan sebesar 31,55\% terhadap resiliensi matematis siswa dan mampu dicapai oleh 12 orang siswa (57\%). siswa memunculkan ide/cara baru dan mencari solusi kreatif terhadap tantangan dalam pembelajaran masalah matematika memberikan sumbangan sebesar $32,2 \%$ terhadap resiliensi matematis siswa dan mampu dicapai oleh 12 orang siswa (57\%). Indikator siswa menggunakan pengalaman kegagalan untuk membangun motivasi diri dalam pembelajaran matematika memberikan sumbangan sebesar $38,1 \%$ terhadap resiliensi matematis siswa dan mampu dicapai oleh 15 orang siswa (71\%). Indikator siswa memiliki rasa ingin tahu, merefleksi, meneliti, dan memanfaatkan beragam sumber dalam pembelajaran matematika memberikan sumbangan sebesar 38,7\% terhadap resiliensi matematis siswa dan mampu dicapai oleh 16 orang siswa (76\%). Indikator siswa memiliki kemampuan mengontrol diri; sadar akan perasaannya dalam pembelajaran matematika memberikan sumbangan sebesar $27 \%$ terhadap resiliensi matematis siswa dan mampu dicapai oleh 8 orang siswa (38\%).

Berdasarkan pencapaian tiap indikator terlihat bahwa indikator yang paling banyak memberikan sumbangan adalah memiliki rasa ingin tahu, merefleksi, meneliti, dan 
Vol 2 No 1 Juli 2021

Jurnal AlphaEuclidEdu

Received:11/04/2021; Resived:20/06/2021; Accepted:10/07/2021

memanfaatkan beragam sumber dalam pembelajaran matematika sebesar $38,7 \%$ dan merupakan indikator yang mampu dicapai siswa sebanyak 16 orang (76\%).

\section{Hubungan Kemampuan Komunikasi Matematis dan Resiliensi Matematis Siswa}

Hasil pengujian hipotesis penelitian dengan uji korelasi menunjukkan nilai signifikan yang dihasilkan yaitu sebesar $0,021<0,05$. Nilai signifikan yang diperoleh tersebut mengakibatkan $\mathrm{H}_{0}$ ditolak atau diterimanya $\mathrm{H}_{\mathrm{a}}$ yang berarti ada hubungan yang signifikan antara kemampuan komunikasi matematis dan resiliensi matematis siswa. Nilai koefisien korelasi sebesar 0,500 berarti korelasi antara kedua variabel adalah korelasi positif, yaitu jika kemampuan komunikasi matematis siswa tinggi maka resiliensi matematis siswa juga tinggi, dan jika kemampuan komunikasi matematis siswa rendah maka resiliensi matematis siswa juga rendah. Nilai korelasi sebesar 0,500 juga menunjukkan kemampuan komunikasi matematis dan resiliensi matematis siswa memiliki tingkat kekuatan hubungan yang tergolong sedang. Terdapat peranan kemampuan komunikasi matematis yang sedang terhadap resiliensi matematis karena ada faktor lain yang mempengaruhi resiliensi matematis itu sendiri. Berdasarkan nilai koefisien determinan $(0,500)^{2}$ x $100 \%=25 \%$ yang berarti kemampuan komunikasi matematis hanya berpengaruh sebesar $25 \%$ terhadap resiliensi matematis., sedangkan $75 \%$ sisanya dipengaruhi oleh faktor lainnya.

Siswa dengan kemampuan komunikasi matematisnya tinggi akan mampu mengekspresikan, menggambarkan, dan menjelaskan gagasan/ide matematika yang dimilikinya ketika menyelesaikan masalah program linear. Ia akan mampu mengekspresikan, menggambarkan, dan menjelaskan gagasan/ide matematika dengan jelas dan logis (NCTM (2000) dalam Asnawati, 2017, h.561). Siswa yang mampu mengekspresikan, menggambarkan, dan menjelaskan gagasan/ide matematika dengan jelas dan logis menunjukkan siswa tersebut memiliki pemahaman konsep matematika yang tinggi. Hal ini sejalan dengan pernyataan Cheah (2007) (dalam Ningrum, 2018) yaitu, "kemampuan komunikasi dibutuhkan untuk menyampaikan pemikiran, perluasan pemahaman serta pemahaman konsep matematika dengan cara menulis untuk menjelaskan, memberi alasan serta memproses pemikiran tentang matematika" (h.213). Siswa yang mempunyai pemahaman konsep yang tinggi akan menunjukkan sikap yang positif yaitu ketekunan, keyakinan, dan tidak mudah menyerah saat menyelesaikan masalah. Sikap positif tersebut dikatakan sebagai resiliensi matematis (Johnston-Wilder dan Lee, 2010b, h.2).

Kurangnya kemampuan siswa ketika merefleksikan benda-benda nyata, gambar, dan diagram ke dalam ide-ide matematika secara tertulis (drawing ability) karena secara keseluruhan siswa masih kurang tepat dalam menentukan daerah penyelesaian pada grafik dari masalah yang diberikan karena tanda pertidaksamaan yang digunakan pada model matematika salah. Ini mengakibatkan kemampuan siswa menjadi kurang untuk memunculkan ide/cara baru dan mencari solusi lain dalam menyelesaikan masalah tersebut. Siswa yang memiliki kemampuan mengekspresikan konsep matematika dengan menyatakan peristiwa sehari-hari dalam bahasa atau simbol matematika secara tertulis (mathematical expression ability) dapat menentukan tanda pertidaksamaan pada 
Vol 2 No 1 Juli 2021

Jurnal AlphaEuclidEdu

Received:11/04/2021; Resived:20/06/2021; Accepted:10/07/2021

model matematika dan variabel pada fungsi objektif tidak sesuai dengan masalah yang diberikan dengan cukup baik meskipun masih terdapat beberapa kesalahan. Siswa tersebut secara rata-rata memiliki rasa ingin tahu, merefleksi, meneliti, dan memanfaatkan beragam sumber dengan baik pula dalam menyelesaikan masalah yang diberikan.

Adanya korelasi positif antara kemampuan komunikasi matematis dan resiliensi matematis siswa tersebut sesuai dengan pendapat Johnston-Wilder dan Lee (2017, h.273) yang menyatakan bahwa mengekspresikan ide-ide matematika dan berbicara tentang pembelajaran matematika dalam suatu komunitas matematika adalah aspekaspek penting dari pengembangan resiliensi matematis yang memungkinkan untuk belajar matematika. Hal ini berarti bahwa mengartikulasikan ide-ide matematika berkontribusi untuk membangun resiliensi matematis (Johnston-Wilder dan Lee, 2008, h.54). Qohar (2011, h.3) menambahkan bahwa kemampuan komunikasi matematis memungkinkan seseorang menggunakan matematika untuk kepentingan dirinya sendiri dan orang lain, juga memungkinkan dirinya dan orang lain memiliki sikap yang positif terhadap matematika. Menurut Johnston-Wilder dan Lee (2010b, h.2) sikap positif terhadap matematika disebut resiliensi matematis. Duggan, Cowan, dan Cantley (2017, h.3172) juga berpendapat bahwa siswa yang memiliki sikap resiliensi matematis ditandai dengan memiliki perkembangan pola pikir dan dipercaya bahwa kemampuan intelektual yang mereka miliki dapat dikembangkan sebagai perbaikan dan umumnya cenderung berprestasi tinggi. Lee (1998, 2006), Mercer and Littleton (2007), Vygotsky (1991) (dalam Jonston-Wilder dan Lee, 2010b, h.4); (Wardah, 2014) menyatakan bahwa berbicara atau berkomunikasi merupakan bagian penting dari pengembangan resiliensi matematis karena dapat meningkatkan kemampuan mengartikulasikan ide, konsep, dan penalaran matematis yang memiliki efek mendalam pada cara peserta didik melihat diri mereka sendiri. Sehingga, agar dapat meningkatkan kemampuan komunikasi matematis atau resiliensi matematis siswa diperlukan pembelajaran yang dapat membantu siswa untuk lebih berani dalam mengkomunikasikan ide matematika yang dimilikinya dan mengembangkan sikap percaya diri, tidak mudah menyerah, dan motivasi siswa untuk terus belajar matematika meskipun dihadapkan dengan kesulitan.

\section{Kesimpulan dan Saran}

\section{Kesimpulan}

Hasil analisis berdasarkan jawaban siswa dalam tes kemampuan komunikasi matematis, diketahui bahwa sebanyak 62\% siswa mampu mencapai indikator mathematical expression ability, sedangkan indikator written text ability dan drawing ability, tidak ada satupun (0\%) siswa yang mampu mencapai siswa tersebut. Sehingga, bisa disimpulkan kemampuan komunikasi matematis matematis yang cenderung dimiliki siswa adalah mathematical expression ability.

Berdasarkan hasil analisis angket resiliensi matematis diketahui bahwa indikator siswa menunjukkan sikap tekun, yakin/percaya diri, bekerja keras dan tidak mudah menyerah menghadapi masalah, kegagalan, ketidakpastian dalam menyelesaikan 
Vol 2 No 1 Juli 2021

Jurnal AlphaEuclidEdu

Received:11/04/2021; Resived:20/06/2021; Accepted:10/07/2021

masalah program linear memberikan sumbangan sebesar $27,8 \%$ terhadap resiliensi matematis siswa dan mampu dicapai oleh 11 orang siswa (52\%), indikator siswa menunjukkan keinginan bersosialisasi, mudah memberi bantuan, berdiskusi dengan sebayanya, dan beradaptasi dengan lingkungannya dalam pembelajaran matematika memberikan sumbangan sebesar $31,55 \%$ terhadap resiliensi matematis siswa dan mampu dicapai oleh 12 orang siswa (57\%), indikator siswa memunculkan ide/cara baru dan mencari solusi kreatif terhadap tantangan dalam pembelajaran masalah matematika memberikan sumbangan sebesar 32,2\% terhadap resiliensi matematis siswa dan mampu dicapai oleh 12 orang siswa (57\%), indikator siswa menggunakan pengalaman kegagalan untuk membangun motivasi diri dalam pembelajaran matematika memberikan sumbangan sebesar $38,1 \%$ terhadap resiliensi matematis siswa dan mampu dicapai oleh 15 orang siswa $(71 \%)$, indikator siswa memiliki rasa ingin tahu, merefleksi, meneliti, dan memanfaatkan beragam sumber dalam pembelajaran matematika memberikan sumbangan sebesar $38,7 \%$ terhadap resiliensi matematis siswa dan mampu dicapai oleh 16 orang siswa (76\%), dan indikator siswa memiliki kemampuan mengontrol diri; sadar akan perasaannya dalam pembelajaran matematika memberikan sumbangan sebesar $27 \%$ terhadap resiliensi matematis siswa dan mampu dicapai oleh 8 orang siswa (38\%) Sehingga dapat disimpulkan resiliensi matematis yang cenderung dimiliki siswa adalah memiliki rasa ingin tahu, merefleksi, meneliti, dan memanfaatkan beragam sumber dalam pembelajaran matematika.

Adanya hubungan yang signifikan antara kemampuan komunikasi matematis dan resiliensi matematis siswa ditunjukkan oleh hasil uji statistik korelasi Pearson Product Moment. Siswa yang memiliki written text ability yang rendah menyebabkan ketekunan, rasa percaya diri, keinginan berdiskusi dan bersosialisasi dengan teman sebayanya, dan mengontrol dirinya juga rendah meskipun siswa tersebut telah menjadikan pengalaman kegagalan sebagai motivasi untuk diri dalam menyelesaikan masalah yang diberikan. Siswa yang memiliki drawing ability yang rendah menyebabkan kemampuan siswa menjadi rendah dalam memunculkan ide/cara baru dan mencari solusi lain dalam menyelesaikan masalah yang diberikan. Siswa yang memiliki mathematical expression ability yang tinggi secara rata-rata memiliki rasa ingin tahu, merefleksi, meneliti, dan memanfaatkan beragam sumber yang tinggi pula dalam menyelesaikan masalah yang diberikan.

\section{Saran}

Penelitian ini diharapkan dapat dimanfaatkan sebagai gambaran bagi guru tentang kemampuan komunikasi matematis dan resiliensi matematis siswa. Sehingga, dapat dilakukan pembelajaran yang dapat meningkatkan kemampuan komunikasi matematis dan resiliensi matematis siswa. Sedangkan bagi peneliti selanjutnya diharapkan memilih sampel menggunakan teknik random sampling agar sampel tersebut memiliki kemampuan yang lebih bervariasi. Selain itu, peneliti selanjutnya diharapkan dapat melakukan wawancara mengenai resiliensi matematis siswa juga. Sehingga apabila terdapat ketidaksetaraan hubungan, peneliti selanjutnya dapat mengetahui apa saja faktor penyebab ketidaksetaraan tersebut. 
Vol 2 No 1 Juli 2021

Jurnal AlphaEuclidEdu

Received:11/04/2021; Resived:20/06/2021; Accepted:10/07/2021

\section{Referensi}

Asnawati, S. (2017). Peningkatan Kemampuan Komunikasi Matematis Siswa SMP dengan Pembelajaran Kooperatif Tipe Teams-Games-Tournaments. Jurnal Euclid, 3(2), 474-603. http://jurnal.unswagati.ac.id/index.php/Euclid/article/view/332/219

Boaler, J. (2009). The Elephant in the Classroom: Helping Children Learn and Love Maths. London: Souvenir Press Ltd.

Duggan, L., Cowan, P., \& Cantley, I. (2017). Are First Year Undergraduates Mathematically Resilienct? A Comparison of a STEM and a non-STEM Discripline in an Institute of Technology. International Journal for Cross-Discriptinary Subjects in Education (IJCDSE), 8(3), 3169-3178, DOI: 10.20533/ijcdse.2042.6364.2017.0425.

Johnston-Wilder, S., \& Lee, C. (2008). Does Articulation Matter when Learning Mathematics?. Proceeding of the British Society for Research into Learning Mathematics, 28(3), 54-59. http://www.bsrlm.org.uk/wpcontent/uploads/2016/02/BSRLM-IP-28-3-10.pdf (2010b). Developing Mathematical Resilience. In: BERA Annual Conference 2010, 1-4 Sep 2010, University of Warwick. https://www.researchgate.net/publication/48989695

. (2017). The Construct Mathematical Resilience. In: Xolocotzin Eligio Understanding Emotions in Mathematical Thinking and Learning, 269-291. https://doi.org/10.1016/B978-0-12-802218-4.00010-8

Kemendikbud. (2014). Peraturan Menteri Pendidikan dan Kebudayaan Republik Indonesia Nomor 59 Tahun 2014 Tentang Kurikulum 2013 Sekolah Menengah Atas/Madrasah Aliyah. Jakarta: Departemen Pendidikan dan Kebudayaan.

National Council Of Teachers Of Mathematics (NCTM). (2000). Principles And Standard For School Mathematics. The National Council Of Teachers Of Mathematics, INC.

Ningrum, R. K. (2018). Meningkatkan Kemampuan Komunikasi Matematis Siswa Menggunakan Problem Based Learning Berbasis Flexible Mathematical Thinking. Yogyakarta: Universitas Negeri Yogyakarta.

Putro, K. Z. (2017). Memahami Ciri dan Tugas Perkembangan Masa Remaja. Yogyakarta: Fakultas Ilmu Tarbiyah dan Keguruan (FTIK) Universitas Islam Negeri Sunan Kalijaga, 17(1), 25-32. http://ejournal.uin-suka.ac.id/pusat/aplikasia

Qohar, A. (2011). Mathematical Communication: What And How To Develop It In Mathematics Learning?. Yogyakarta State University: International Seminar and the Fourth National Conference on Mathematics Education 2011. https://core.ac.uk/download/pdf/11058861.pdf

Rahmawati, N. S., Bernard, M., \& Akbar, P. (2018). Analisis Kemampuan Komunikasi Matematik Siswa SMK pada Materi Sistem Persamaan Linear Dua Variabel (SPLDV). Cimahi: IKIP Siliwangi, 1(2), 344-352. http://www.jonedu.org/index.php/joe/article/view/74 
Vol 2 No 1 Juli 2021

Jurnal AlphaEuclidEdu

Received:11/04/2021; Resived:20/06/2021; Accepted:10/07/2021

Rifdah, \& N Priatna. (2020). The Relationship between Mathematics Resilience and Mathematics Communication Skill. Journal of Physics: Conference Series, 1521(2020), 1-5, DOI: 10.1088/1742-6596/1521/3/032037.

Wardah, W. (2014). Metacognitive Reading Strategy Enhancing English Reading Comprehension. At-Turats, 8(1). https://doi.org/10.24260/at-turats.v8i1.107

Wulandari, Stevanie. (2014). Kemampuan Komunikasi Matematis Siswa Ditinjau dari Gaya Belajar pada SMA Negeri 10 Pontianak. Pontianak: FKIP Universitas Tanjungpura. 